\title{
JIHAD DALAM PERSPEKTIF HADIS
}

\section{Kamarudin}

STAIN Datokarama Palu, Jl. Diponegoro 23 Palu e-mail: kamaruddin_67@yahoo.co.id

\begin{abstract}
Jihâd is one of the Islamic main terms which is frequently misunderstood by the group of non Muslims. They tend to perceive jihâd as a holy war against the disbelievers. Based on this, to them, jihâd is identical to violence. The question is wither Islam truly a religion of violence?, or it is only a misunderstanding towards jihâd in Islam. It is true that the term jihâd possesses a significant position among the Muslims that many of them devote themselves to God by jihâd. Jihâd in Islam has passed over two periods, the period of Mecca and the period of Medina with differentf emphasis on jihad.
\end{abstract}

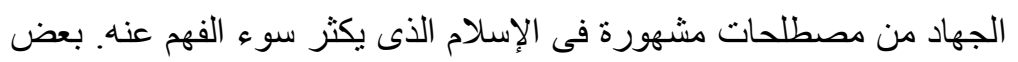

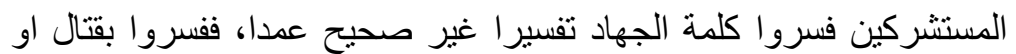

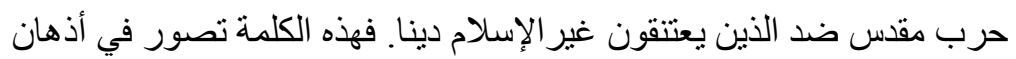

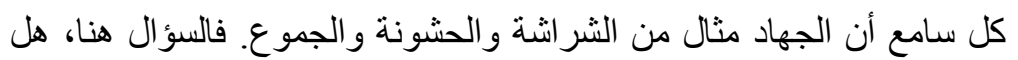

صحيح أن الإسلام دين حربى ام هناك خطأ فى تفسير معنى الجهاد؟ حقيقة،

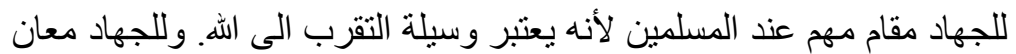

واسعة اى كل جهذ يبذل فى سبيل ابتغاء مرضاة الله. من اجل نللك، كان من

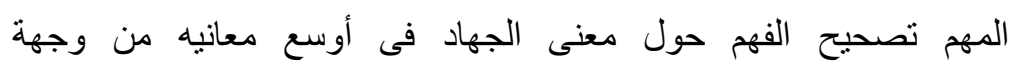

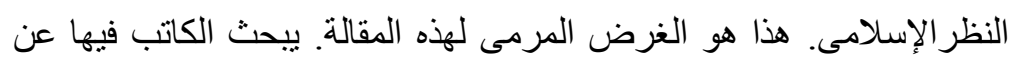

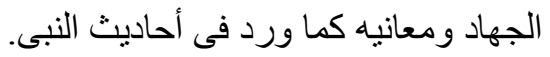

Kata Kunci: jihad, perang suci, terorisme, kekerasan, perspektif hadis 


\section{PENDAHULUAN}

Jihad merupakan salah satu ajaran Islam selalu menjadi sorotan dari berbagai golongan. Hal ini dapat dilihat dari berbagai persepsi yang ada tentang jihad. Istilah tersebut sering dipahami sebagai perang suci. Pemahaman tersebut muncul dari para ilmuan Muslim dan non Muslim, terutama dari kalangan pengamat Barat, yang memahami jihad sebagai tindakan pemaksaan dan penyerangan kepada orang lain agar masuk Islam. Dalam konteks ini, Islam dipahami sebagai agama yang disebarkan melalui perang dan pertumpahan darah (Sa'id Hâwî, 1979: 3).

Barat memahami jihad sebagai salah satu ajaran Islam yang disimbolkan dengan kekerasan, kekejaman dan teror. Islam di Barat dipandang secara sinis sebagai agama yang tidak bermoral. Pemahaman ini ditopang oleh data-data empiris, yaitu perilakuperilaku kaum fundamentalis Islam yang sering melakukan aksi teror, dan memaksakan kehendak dengan malakukan tindakan anarkhis, serta menanamkan bibit kerusakan dan perpecahan di tengah-tengah perdamaian dan ketentraman dunia. (Mehden, 1983:18-25).

Sebagian umat Islam memahami jihad dengan makna yang sangat sempit, padahal makna jihad itu cukup luas, yaitu seluruh aktivitas manusia bisa berorientasi jihad di jalan Allah swt. Fuqahâ, memahami jihad dalam bentuk dakwah, seperti Imam Hanafi, yang memahami jihad sebagai dakwah terhadap orang kafir agar mau memeluk Islam dengan cara memerangi bila mereka menolak ajakan itu. Kemudian pengikut Imam Malik, jihad diartikan sebagai peperangan umat Islam terhadap orang-orang kafir untuk menegakkan agama Allah, begitu pula dengan pengikut Imam Syafi'i dan Hanbal ( 'Azzâm, 1992:5-6).

Jihad bagi umat Islam adalah salah satu usaha untuk merealisasikan kehendak Allah swt. yang diekspresikan melalui agamanya. Dalam pengembangan dan pelestarian agama Islam, jihad menempati posisi strategis dan signifikan dalam ajaran Islam. Dalam perjalanan sejarah Islam, para pejuang Islam, dalam memperluas wilayah kekuasaannya, sering melakukan penyerangan dan peperangan dengan agama lain. Di samping itu, terdapat banyak nas $\square$ Alquran maupun hadis yang menganjurkan untuk berjihad. 
Untuk melaksanakan perintah Allah dan Rasul-Nya, umat Islam harus berusaha dengan mengerahkan segala kemampuan untuk mewujudkan perintah tersebut. Untuk menjadi Muslim yang baik, seseorang harus selalu berjuang demi kepentingan agama Islam (jihad). Seseorang harus memiliki kemampuan dan mengimplementasikan jihad dalam makna yang esensial (Al-Bajûrî, t.th:268).

Pemahaman yang sempit tentang jihad sering kali melahirkan kekerasan, pembunuhan, dan peperangan sehingga ketentraman dan kedamaian dunia sulit diwujudkan. Sehubungan dengan hal tersebut, makna jihad perlu dikaji ulang dengan menggunakan perspektif hadis.

\section{PENGERTIAN JIHAD}

Secara etimologis, kata jihad berasal dari kata al-juhd, yaitu upaya, kesungguhan dan kesulitan (Munawwir, 1997:217). Kata jihad berakar dari kata al-jahd, al-majhud, al-juhd, bermakna al-tâqah, "kemampuan". Sementara kata al-majhud memiliki makna al-laban al-lazî ukhrija zubdahu, "susu yang dikeluarkan intisarinya". Susu tersebut sangat sulit dikeluarkan kecuali dengan upaya yang sulit dan kesungguhan. Sementara makna yang memilki kedekatan dengan kata kesulitan adalah "keras", sungguh-sungguh" ( Zakariyah, 1979:487).

Menurut Abdullah, kata jihad berasal dari akar kata jahada yajhadu, jahdan, yang artinya sama dengan jadda atau bersungguhsungguh dan berusaha maksimal mungkin. Akar kata jahada dibentuk menjadi thulâthi mazîd dengan menambahkan alif setelah fâ' fâ'il, sehingga menjadi jâhada, yujâhidu, mujâhadatan (Abdullah, 1978: 11).

Dari penjelasan makna akar kata ini, dapat dipahami bahwa jihad itu memiliki makna upaya yang sungguh-sungguh, upaya yang sulit, usaha maksimal, keras, dan kuat. Sedangkan makna jihad menurut pengertian terminologinya adalah mengerahkan segala kemampuan untuk menangkis serangan dan menghadapi musuh yang tidak nampak seperti hawa nafsu, syaithan dan musuh yang tampak seperti orangorang kafir (Al-Asfahânî, t.th.:208).

Berpijak dari analisis semantik di atas, dapat diambil suatu pemahaman yang utuh tentang makna jihad, yaitu jihad adalah kesukaran, kesulitan, kemampuan, kekuasaan, pengorbanan, ujian, dan puncak dari masalah. Dikatakan kesukaran karena di dalamnya banyak 
rintangan-rintangan dan musuh-musuh yang benar-benar sukar diatasi tanpa kemampuan, baik kemampuan fisik seperti kemampuan badan yang sehat dan kemampuan material maupun kemampuan non material, seperti kemampuan keilmuan dan kepandaian.

Dalam berjihad dibutuhkan kekuasaan dan pengorbanan. Kekuasaan yang dimaksud adalah penguasaan orang yang berjihad tentang persoalan-persoalan yang dihadapinya atau yang akan diatasinya. Selain itu, dalam berjihad dibutuhkan baik pengorbanan harta dan keluarga maupun pengorbanan segala sesuatu yang dibutuhkan dalam berjihad.

Melihat makna jihad yang general ini, maka jihad tidak dapat dipahami sebatas perjuangan fisik melawan musuh-musuh yang tampak seperti melawan orang-orang kafir, melawan orang-orang munafik atau melawan orang-orang yang telah berbuat zalim, tetapi lebih jauh dari makna itu, seperti melakukan perlawanan terhadap musuh-musuh yang tidak tampak, misalnya melawan hawa nafsu yang selalu mengajak kepada hal-hal yang merusak martabat kemanusiaan dan melawan kebodohan yang dapat menghambat perkembangan intelektual.

Dalam The Concise Encyclopedia of Islam, kata jihad disebutkan berasal dari kata Arab, "jahd", yang sama dengan makna "effort" yang bermakna:

Divine institution of warfare to extend Islam into the dar al-harb (the non Islamic territories which are described as the "abode of struggle" or of disbelief) or to defend Islam from Danger. Adult males must participate if the need Islam arises, but not all of them provided that "a sufficient number" (fard al-kifâyah) take it up (Glasse, 1989:209).

Dalam bahasa Indonesia dapat diartikan:

Perang suci (bersifat ilahiyah) untuk menyiarkan Islam ke dâr al-harb (wilayah-wilayah non Muslim yang disebut sebagai tempat perjuangan atau wilayah orang yang tidak beriman) atau untuk mempertahankan Islam dari bahaya. Laki-laki dewasa diwajibkan ikut serta di dalamnya bilamana diperlukan, akan tetapi tidak untuk seluruhnya, cukup dengan sekelompok orang saja (fard al-kifâyah).

Makna jihad di atas telah mengalami derivisi dan tercerai dari makna jihad yang lebih komprehensif. Definisi jihad telah mengalami reduksi makna sehingga jihad tidak hanya dipahami sebatas perjuangan atau peperangan suci melawan orang-orang kafir sebagai musuh Islam, tetapi bisa saja berkonotasi merawat orang tua disaat 
lanjut usia, berjuang melawan kebodohan, mencari ilmu pengetahuan atau melaksanakan haji dengan haji mabrur.

Banyak hadis nabi yang mengungkapkan makna jihad, tetapi tidak ditemukan dalam hadis nabi yang menjelaskan secara eksplisit perintah berjihad dengan menggunakan senjata melawan orang kafir, atau musuh-musuh Islam. Jihad dalam kebanyakan hadis nabi justru lebih berorientasi kepasa makan berjihad terhadap kedua orang tua, kebodohan, kemiskinan, dan berjuang mendapatkan haji mabrur. Hal ini dapat dilihat dalam beberapa hadis nabi berikut ini:

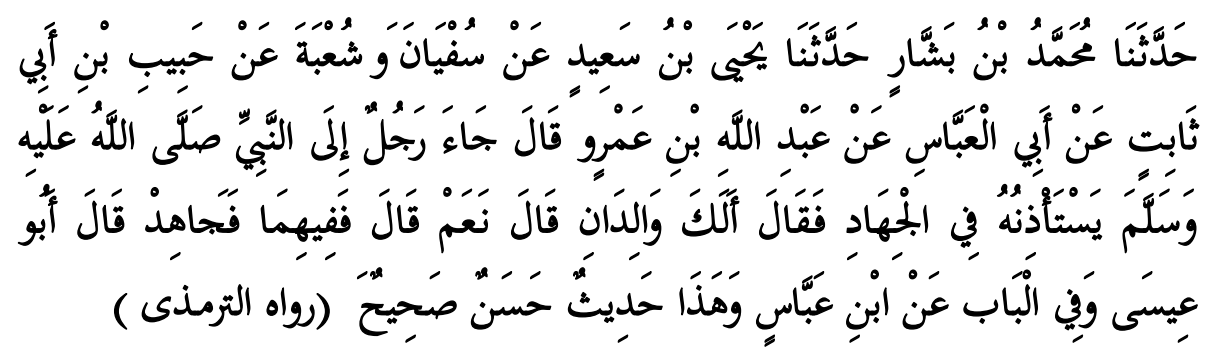

Terjemahnya:

Kami telah disampaikan Muhammad bin Bashshâr, telah disampaikan kepada kami Yahyâ bin Sa'îd dari Sufyân dan Shu'bah, dari Habîb bin Abî Thâbit dari Abî al-'Abbâs dari 'Abd Allâh bin 'Amr berkata: Seorang laki-laki telah mendatangi Nabi saw, ia sengaja meminta izin untuk berjihad, maka Nabi berkata: Apakah kamu mempunyai orang tua, lakilaki itu menjawab: ya, lalu Nabi berkata: Maka kepada keduanya kamu berjihad. Manurut Abu 'Isa di dalam satu pembahasan dari Ibn 'Abbâs, bahwa hadis ini adalah hasan $s \square$ ahîh

Dalam hadis lain disebutkan sebagai berikut:

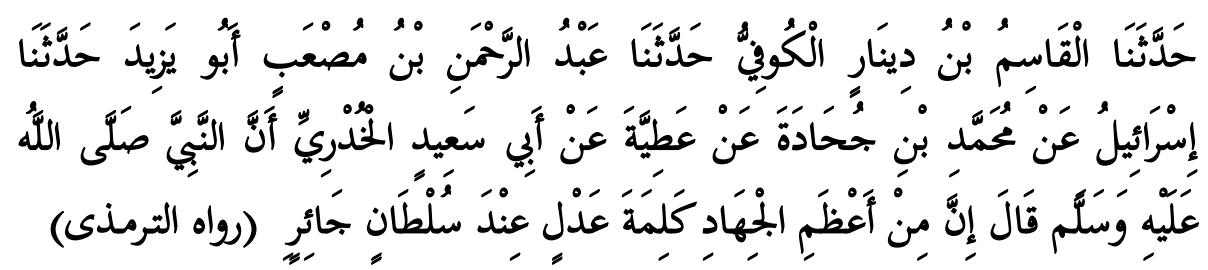

Terjemahnya :

Kami diberitakan Qâsim bin Dînâr al-Kûfiyyu, diberitakan

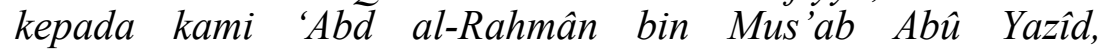
diberitakan kepada kami Isrâ'îl dari Muhammad bin Juhâdah 
dari Ât $\square$ iyyah dari Abî Sa'îd al-Khudrî, bahwasanya Nabi saw., telah berkata: Sesungguhnya dari semua jihad yang lebih besar adalah jihad ucapan yang adil (benar) di depan penguasa yang kejam.

Kamudian nabi juga pernah menyampaikan bahwa yang termasuk jihad di jalan Allah adalah menjauhkan diri dari kemaksiatan, seperti hadis nabi berikut:

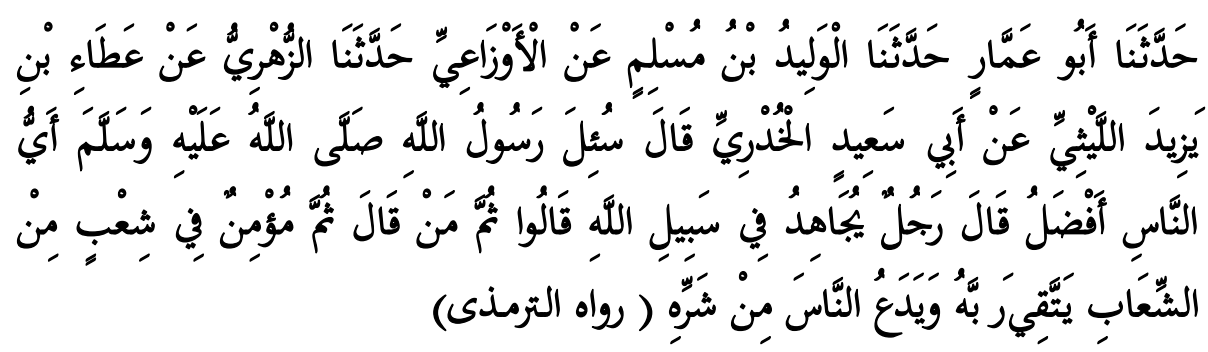

Terjemahnya :

Kami disampaikan abu 'Ammar, kami disampaikan al-Walid bin Muslim dari al-Auzâ' '̂, kami disampaikan al-Zuhrî dari 'At $\square \hat{a}$ ' ibn Yazî̀ al-Laishî̀ dari Abî̀ Sa'îd al-Khudrî berkata: Rasulullah saw. pernah ditanya tentang orang yang paling afdal, Nabi menjawab: Laki-laki yang berjihad di jalan Allah, lalu mereka bertanya lagi, kemudian siapa lagi, kemudian Nabi menjawab: orang mukmin (yang berjalan di bukit) bertakwa kepada Tuhannya dan menyeruh manusia meninggalkan kejahatan

Di samping itu, nabi pernah mengatakan bahwa yang termasuk jihad adalah jihad dengan melaksanakan haji dan mendapatkan haji mabrur, seperti teks hadis nabi:

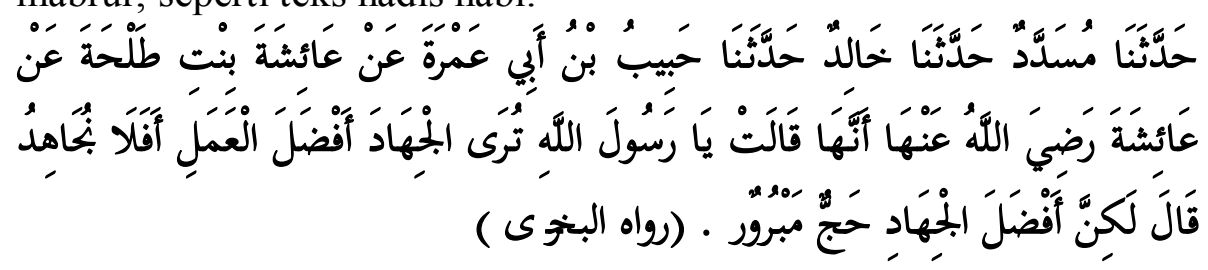

Terjemahnya :

Kami disampaikan Musaddad, kami disampaikan Khâlid, kami disampaikan Habîb ibn Abî 'Amrah dari 'Aishah bint Talhah dari 'Aishah ra. Telah berkata kepada Rasulullah: Ya Rasulullah, kami telah melihat jihad adalah amal yang paling 
utama, pada hal kami tidak berjihad. Lalu Nabi berkata: Tidak, akan tetapi jihad yang paling utama adalah haji mabrur.

Dalam teks-teks hadis nabi tersebut, tidak ditemukan anjuran untuk melakukan jihad dengan mengangkat senjata atau melakukan perlawanan fisik terhadap musuh-musuh Islam dengan menggunakan pedang, seperti yang dipahami kebanyakan orang Barat. Dalam kajian hadis nabi, makna jihad ditemukan antara lain anjuran untuk mengungkap kebenaran kepada pemimpin yang berbuat zalim, walaupun teguran itu merasa berat untuk dilakukan, tetapi menurut nabi itu adalah salah satu bentuk jihad di jalan Allah.

Demikian juga seorang anak yang merawat orang tuanya yang telah lanjut usia, juga dianggap berjihad di jalan Allah. Kafakiransalah satu wacana jihad yang juga diungkap dalam hadis nabikarena orang fakir adalah orang yang berusaha tetapi tidak mencukupi kebutuhan hidupnya.

Penyebab kefakiran atau kemiskinan adalah kebanyakan sikap berdiam diri, enggan, tidak mau berusaha dan kurang bergairah untuk menggali sumber daya alam (Shihab, 1996:449-450). Kemiskinan bukan bermula dari struktur sosial, tetapi berasal dari karakteristik khas orang-orang miskin. Orang-orang miskin menjadi miskin karena ia tidak mau bekerja keras untuk melakukan perubahan pada dirinya, tidak hemat, sedikit mempunyai rencana, kurang mempunyai jiwa wiraswasta, kurang fasilitas, sulit memunculkan hasrat berprestasi dan sebagainya (Rahmat, 1989:92).

Karena kemiskinan, orang menjadi buta kehidupan dan menyimpang dari jalan Allah. Kemiskinan dalam satu sisi menimbulkan kerawanan-kerawanan sosial. Di sisi lain, kemiskinan seringkali menjadikan seseorang menzalimi diri sendiri, seperti yang biasa terjadi pada orang-orang miskin yang harus melakukan konversi agama karena kemiskinannya. Keimanan mereka lucuti karena hanya ingin memenuhi tuntutan hidup. Ada pula orang yang harus meninggalkan agamanya hanya karena menikah dengan seorang kaya-raya yang berlainan agama. Untuk mengatasi hal ini, perlu dilakukan pemberdayaan ekonomi umat agar hal ini tidak melanda umat Islam, yang kebanyakan keadaan ekonominya berada pada garis kemiskinan. 


\section{PERKEMBANGAN MAKNA JIHAD}

Perkembangan makna jihad, dapat dilihat pada dua fase, yaitu fase Mekah dan fase Madinah.

\section{Perkembangan Makna Jihad pada Periode Mekah}

Term jihad, sewaktu nabi berada di Mekah atau sebelum hijrahnya ke Madinah, belum menjadi perhatian yang serius karena perhatian para sahabat tertuju kepada pengkajian dan pemahaman Alquran. Secara umum, jihad yang dilakukan nabi adalah jihad dalam bentuk non fisik. Indikasi ini terlihat pada awal-awal perkembangan Islam, nabi telah melarang sahabatnya untuk menulis hadis, salah satu yang melatarbelakangi adanya larangan tersebut ialah karena ada kekhawatiran nabi akan terjadi pencampurbauran antara hadis nabi dengan teks Alquran. Jadi, perhatian para sahabat nabi ialah adalah mengkaji dan menghafal Alquran, baik dengan kembali mengkaji ingatan para sahabatnya maupun dari bahan teks tertulis (Shalih, 1995: 27).

Untuk merespon pendapat di atas, tentang perintah jihad dalam bentuk fisik, secara umum pada awal-awal Islam belum nampak, dapat diperhatikan ayat-ayat Makiyah. Ayat yang pertama turun berdasarkan konversi surah adalah Q.S Al-Furqân (25):52. Term jihad termaktub dalam ayat ini adalah berupa kata jâhid (dalam bentuk fi'il amar) dan jihâdun (isim masdar yang berfungsi sebagai maf'ûl mutlaq berarti $l i$ al-ta'kîd "sungguh-sungguh"). Kata jihad dalam konteks ayat ini adalah menahan diri, untuk tidak mengikuti orang-orang kafir dan berupaya menggali dan mensosialisasikan Alquran, bukan jihad dalam bentuk perang secara fisik melawan orang-orang kafir. Indikator makna ini diungkap dari kata jihad yang beriringan dengan frasa falâ tuti' al-kâfirîn dan kata jihad tersebut disertai oleh kata bih (damîr muttasîl hâ'), ini kembali kepada Alquran . Jihad terhadap orangorang kafir tersebut dengan menggunakan Alquran. (Abû al-Baqâ', 1987: 988).

Ayat berikutnya adalah Q.S Al-An'âm (6):109; Q.S. Al-Nahl (16):38. Perintah jihad dalam ayat ini berupa jahdun. Kata jahdun disertai kata aiman yang bermakna "sumpah". Berarti makna jihad dalam konteks ayat ini adalah sungguh-sungguh dalam bersumpah, ayat tersebut disusul kemudian oleh Q.S. Al-Nahl (16):110 dan Q.S. 
Al-'Ankabût (29):69. Dalam kedua ayat tersebut, kata jihad yang menggunakan kata kerja jâhadh . Ayat pertama, yaitu kata kerja

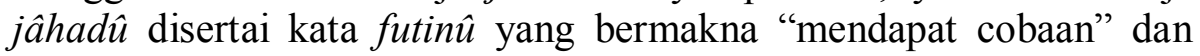
kata sâbarû. Berarti kata jâhadî dalam konteks ayat ini adalah ujian yang serius terhadap kualitas keimanan umat Islam dari siksaan dan kekejaman orang-orang musyrik Mekah (Husayn, 1972:355).

Awal perkembangan Islam, kezaliman dan kedustaan sangat merajalela dan terdapat di mana-mana, sehingga jihad terhadap kezaliman dan pendusta Allah swt. dan kenabian Muhammad saw., tidak harus diperangi dalam arti mengangkat senjata, akan tetapi harus dinasehati dengan pendekatan Alquran dan hadis nabi. Ini dibuktikan beberapa hadis nabi yang tertulis pada awal perkembangan Islam. Nabi sering menyampaikan pesan-pesan agama melalui hadisnya Kezaliman yang dilakukan mereka adalah kezaliman terhadap dirinya sendiri, karena mereka menyembah berhala dan mendustakaan ayatayat Allah swt.

\section{Perkembangan Makna Jihad Periode Madinah}

Perkembangan makna jihad periode Madinah, tentu berbeda dengan makna jihad pada periode Mekah karena perkembangan ilmu pengetahuan semakin pesat dan daerah kekuasaan Islam bertambah luas. Ayat-ayat Alquran yang membicarakan masalah jihad sangat variatif maknanya. Terdapat 33 ayat Alquran yang berbicara tentang jihad sehingga makna-makna yang terkandung di dalamnya juga beragam.

Ayat pertama yang tergolong ayat Madaniyah, yaitu Q.S Al'Ankabût (29):8:

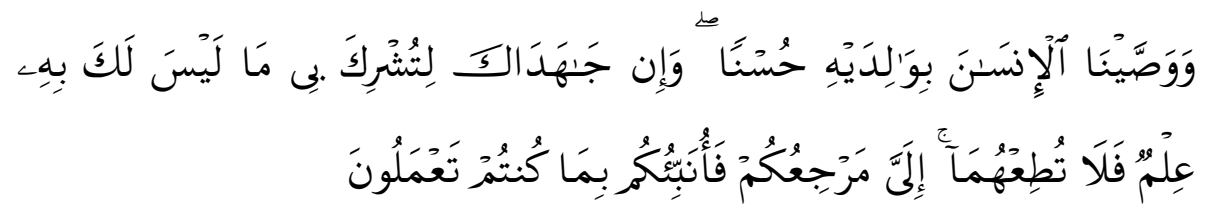

Terjemahnya :

Dan Kami wajibkan manusia (berbuat) kebaikan kepada dua orang ibu- bapaknya, dan jika keduanya memaksamu untuk mempersekutukan aku dengan sesuatu yang tidak ada pengetahuanmu tentang itu, Maka janganlah kamu mengikuti keduanya. hanya kepada-Ku-lah kembalimu, lalu aku kabarkan kepadamu apa yang telah kamu kerjakan. 
Dalam ayat tersebut, kata jâhadâka beriringan dengan tushrika dan 'ilm. Kata tersebut bermakna memaksa dengan keras menyekutukan Allah. Ayat tersebut dapat dipahami sebagai larangan untukk menyekutukan Allah meskipun paksaan itu datangnya dari orang tua sendiri. Sedangkan kata 'ilm merupakan illat bagi sikap ketidaktaatan terhadap paksaan yang keras. Artinya, paksaan untuk menyekutukan Allah sekalipun datangnya dari orang tua, jika diketahui secara pasti masalahnya, tidak boleh diikuti, tetapi orang tua tetap harus dihormati.

Sedangkan makna jihad yang bermakna perjuangan fisik melawan orang musyrik atau kafir Quraish dipahami dari ayat tentang izin Allah untuk berperang secara fisik melawan orang-orang kafir. Izin perang dari Allah swt. disebutkan dalam Q.S Al-Hajj (22):39. Ayat-ayat yang turun setelah surah ini dipahami sebagai perlawanan fisik melawan orang-orang kafir, meskipun tidak seluruhnya ayat-ayat Alquran turun sesudah adanya ayat izin perang bermakna jihad perlawanan fisik. Ayat yang turun sesudah izin perang antara lain terdapat dalam Q.S Al-Taubah (9) dan Q.S Al-Tahrîm (66):9. Kedua ayat ini, jihad diartikan sebagai perjuangan fisik melawan orang-orang kafir dan orang-orang munafik.

Berpijak dari paparan makna jihad yang terdapat dalam Alquran dan hadis nabi saw. baik ayat-ayat Makiyah maupun Madaniyah, telah menjelaskan secara utuh dan integral, bahwa makna jihad tidak terbatas dan tidak memiliki makna yang sangat sempit, seperti pemahaman mereka di dunia Barat atau kalangan muslim tertentu sebagai perjuangan fisik terhadap musuh-musuh Allah, akan tetapi jihad memiliki makna yang general dan bersifat menyeluruh.

Dalam ayat Makiyah atau hadis yang dikeluarkan oleh nabi sewaktu beliau berada di Mekah yang menganjurkan melaksanakan jihad dengan perjuangan fisik melawan orang-orang kafir atau orangorang yang musyrik tidak ditemukan. Tetapi pada kenyataannya banyak ayat ditemukan atau hadis menganjurkan untuk menjaga dan mengkaji Alquran, menjaga kualitas keimanan dan meningkatkan keilmuan. Walaupun ada perintah jihad dengan perlawanan fisik, Nabi jarang melakukannya, kecuali dalam keadaan terdesak

Sebagai konklusi awal dan masih bersifat hipotetik, makna jihad yang terdapat dalam Alquran sewaktu nabi berada di Mekah, tidak 
ditemukan perintah untuk melakukan jihad dalam bentuk perlawanan fisik. Begitupula dalam hadis nabi, tidak ditemukan anjuran untuk melaksanakan jihad dengan mempergunakan fisik (mengangkat senjata untuk berperang melawan orang-orang kafir dan munafik).

Perintah Allah berjihad dengan perlawanan fisik, setelah nabi hijrah ke Madinah. Walaupun ada anjuran Allah untuk melakukan jihad dengan kekuatan fisik, hanya terdapat dalam beberapa ayat. Perintah jihad dengan melakukan perlawanan fisik, bukan melakukan jihad dengan mengangkat senjata semata, tetapi bisa bermakna lain. Islam tidak menganjurkan atau mengajarkan perpecahan, pertikaian dan teror, tetapi Islam adalah agama rahmat bagi seluruh alam.

Adapun orang-orang yang memahami bahwa Allah swt. telah menganjurkan untuk melakukan jihad dalam bentuk fisik, hanya penafsiran saja, sehingga mereka memahami ada dua ayat yang menganjurkan untuk berjihad dalam bentuk fisik. Hal ini didasari hasil analisis setelah melihat beberapa ayat berkonotasi jihad.

\section{ANALISIS}

Dalam beberapa ayat Alquran dan hadis nabi, baik periode Mekah maupun periode Madinah, hanya dua ayat yang dapat dipahami yang mengisyaratkan berjihad secara fisik. Dengan pemahaman itu, banyak umat Islam yang menafsirkan dan melakukan jihad dengan perlawanan fisik kepada musuh-musuh Islam dalam bentuk perang dan teror. Pemahaman dan tindakan seperti itu kurang terpuji karena, baik Alquran maupun hadis nabi tidak menginginkan adanya kekerasan dan penindasan yang berlebihan terhadap pemeluk agama lain.

Hal ini dapat dipahami dari perjuangan nabi dalam menyikapi para pembangkang agama dan pendusta agama Islam, baik ketika nabi berada di Mekah, maupun di Madinah. Bahkan nabi menghabiskan waktunya untuk membumikan Alquran di tengahtengah masyarakat yang butuh terhadap Alquran. Nabi menganjurkan para sahabatnya untuk menghafal dan mengkaji Alquran. Oleh karena itu, apa yang dilakukan nabi dalam menyikapi semua persoalan keagamaan dan kemasyarakatan, hendaknya dapat menjadi cermin di di era sekarang, yaitu banyak mengkaji, menghafal, dan memperkenalkan Alquran kepada mereka yang belum mengenal Alquran dengan cara yang bijak dan lemah-lembut. 
Apa yang telah dilakukan oleh nabi dapat diikuti oleh masyarakat modern karena tidak sedikit umat Islam sekarang ini yang belum memahami Alquran secara mendalam. Oleh karena itu, menurut hemat penulis, perlu dilakukan kajian-kajian dan penafsiran Alquran berdasarkan kebutuhan masyarakat untuk menjawab persoalan-persoalan umat dewasa ini. Mengkaji Alquran dan memperkenalkannya ke tengah-tengah masyarakat dapat bernilai jihad di sisi Allah swt.

Membumikan dan mengungkap rahasia-rahasia Alquran sangat urgen dilakukan oleh umat Islam karena Alquran dan hadis nabi merupakan petunjuk bagi manusia, baik dalam bermuamalah maupun dalam berubudiyah. Oleh karena itu, umat Islam dituntut agar memiliki kemampuan dan kecakapan membumikan Alquran di tengah-tengah masyarakat modern, baik di lingkungan keluarga maupun di lingkungan masyarakat. Artinya, Alquran dan hadis nabi harus dijadikan dasar dalam menjawab segala persoalan yang dihadapi umat Islam saat ini.

Mencermati persoalan yang dihadapi umat dewasa ini, Alquran dan hadis sebagai sumber kajian, atau berjihad dengan Alquran, sangat urgen untuk dilakukan. Maksudnya, manusia tidak dapat melepaskan diri dari lingkungan keluarga yang qur'âniyyah, baik secara individual maupun secara kolektif. Dengan kata lain, dalam keadaan bagaimanapun, manusia harus menjadikan Alquran sebagai petunjuk dalam menjalani kehidupannya. Jika ini yang dilakukan manusia setiap saat, maka setiap saat pula mereka digolongkan sebagai manusia yang selalu melakukan jihad di jalan Allah.

Memahami makna jihad dengan analisis kekinian, tetap dianggap urgen untuk dilakukan dan dibicarakan, baik di forum nasional maupun internasional. Menurut hemat penulis, apa yang dilakukan nabi pada awal-awal perkembangan Islam, seperti melakukan pengkajian terhadap Alquran dan memperkenalkannya kepada masyarakat, merupakan hal yang perlu pula dilakukan pada masyarakat di era global. Alasannya ialah masih banyak orang Islam di era modern yang tidak mampu membaca Alquran apalagi memahami kandungan dan isinya.

Jika pada masa nabi, terutama pada awal-awal perkembangan Islam, banyak orang yang tidak mengikuti Alquran, bukan karena 
mereka tidak mengerti maksudnya, tetapi mereka belum memahami betul kehadiran Alquran sebagai petunjuk. Berbeda dengan orangorang yang hidup di era modern, mereka sudah mengetahui dan mengerti bahwa Alquran adalah sebagai petunjuk bagi umat manusia dalam kehidupannya, akan tetapi mereka enggan menjadikan Alquran sebagai petunjuk. Kedua kelompok ini pada dasarnya sama, yaitu tidak menjadikan Alquran sebagai pedoman hidup. Jika demikian, perjuangan nabi dalam memperkenalkan dan memasyarakatkan Alquran, sangat perlu disikapi sebagai perbuatan jihad di jalan Allah swt., yaitu jihad dalam bentuk non fisik, bukan jihad seperti yang dipahami Barat selama ini.

Barat menilai bahwa jihad dalam Islam (Alquran dan hadis), selalu berorientasi negatif. Misalnya, jihad harus dilakukan dengan kekerasan, pemaksaan, dan perang. Memang ada beberapa perilaku orang-orang atau kelompok-kelompok tertentu yang yang melakukan anarkis, pengrusakan, dan terror dengan mengatasnamakan jihad dalam Islam. Tindakan seperti itu, pada saat ini, tidak dapat dipungkiri keberadaannya karena ada kelompok-kelompok tertentu yang tega membunuh, atau melakukan bunuh-diri untuk melawan kezaliman dengan mengatasnamakan jihad. Perbuatan mereka, menurut hemat penulis, bukan jihad seperti yang dianjurkan oleh nabi karena Islam bukan agama kekerasan, melainkan agama kedamaian dan ketentraman.

Begitupula di Barat, jihad selalu diidentikkan dengan perjuangan dengan kekerasan. Cara pandang ini, menurut penulis, di samping karena ketidaksenangan mereka terhadap ajaran Islam, juga karena banyak umat Islam yang memperlihatkan perilaku kurang simpatik dan melenceng dari konsep jihad yang terdapat dalam Alquran dan hadis nabi.

Perintah Allah swt. untuk berjihad dengan menggunakan Alquran dapat ditemukan dalam Alquran secara implisit, dan perintah ini masih urgen untuk dilakukan pada masa kini, yaitu Q.S Al-Furqân (25): 52:

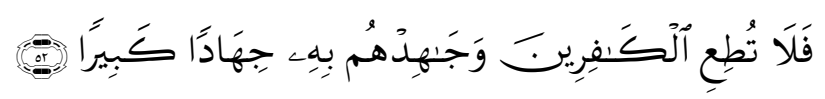

Terjemahnya: 
Maka janganlah kamu mengikuti orang-orang kafir, dan berjihadlah terhadap mereka dengan Alquran dengan jihad yang besar.

Dalam ayat tersebut, klausa jâhidhum disertai kata bih. Kata jâhid adalah bentuk kata perintah yang berarti perintah untuk berjihad. Perintah berjihad dalam ayat tersebut, menggunakan Alquran sebagai sarana jihad terhadap orang-orang kafir.

Kekafiran yang disebutkan dalam Alquran adalah ketidak mauan menjadikan Alquran sebagai pedoman hidup Jika demikian halnya, maka masih banyak umat yang mengaku Islam, tetapi enggan melaksanakan ajaran dan perintah Alquran, mereka mengetahui dan memahami bahwa ajaran dan konsep Alquran adalah benar, tetapi mereka tidak mau menjalankannya. Perilaku seperti ini termasuk golongan yang ingkar terhadap Alquran dan hadis nabi, seperti mereka mengerti bahwa salat dalam Islam dianjurkan oleh Alquran dan hadis nabi, apabila ditinggalkan mendapat dosa, tetapi pada kenyataanya masih banyak orang Islam, tetapi di natara mereka yang tidak mengerjakan salat. Perbuatan mereka menurut penulis, termasuk perbuatan orang-orang kafir sebagaimana yang dimaksud dalam Alquran.

Jika demikian halnya, tantangan umat Islam untuk memperkenalkan sekaligus menyadarkan mereka yang tidak mau menjadikan Alquran sebagai petunjuk dalam kehidupannya- agar mereka mau menjadikan dan meyadari betul bahwa kehadiran Alquran di tengah-tengah manusia - sangat dibutuhkan. Mereka berusaha untuk memberikan pemahaman kepada orang-orang yang tidak mau menjalankan misi Alquran dan dilakukan dengan sepenuh hati dengan hati yang ikhlas, sehingga mereka termasuk golongan orang-orang yang berjihad di jalan Allah swt.

Menurut penulis, jihad di jalan Allah ialah apa pun yang dilakukan oleh manusia dengan dasar usaha yang sungguh-sungguh dan bertekad untuk melaksanakannya dengan ikhlas sesuai dengan petunjuk Alquran dan hadis nabi.

Mengkaji Alquran, seperti yang dilakukan oleh nabi pada awalawal perkembangan Islam, masih sangat aktual untuk dilakukan saat ini. Menurut Rashîd Ridâ, kehadiran Alquran sebagai petunjuk dalam segala aspek kehidupan manusia akan selalu memberikan inspirasi bagi setiap yang membacanya (Ridâ, t.th.:158). Menurut Ibn Kathîr 
(dalam Al-Hamîsî, 1990:381), siapa pun yang membaca dan memahami Alquran akan mendapat petunjuk berbagai hal dalam kehidupan. Kedua pendapat tersebut di atas dipertegas oleh (AlZuhaylî, 1990:134) bahwa Alquran itu adalah petunjuk jalan untuk mencari kebenaran dari segala ketentuan yang ada, baik secara eksplisit maupun implisit dalam ayat-ayat qauliyyah dan qauniyyah.

Berdasarkan beberapa pendapat di atas, umat Islam pada masa kini, harus banyak melakukan pengkajian terhadap Alquran dan hadis nabi sesuai dengan kondisi dan kultur di mana mereka berada, dengan berbagai pendekatan interdisipliner dan kontemporer. Tujuannya ialah agar jihad di jalan Allah tidak dipahami secara sangat sempit dan eksklusif, tetapi harus dipahami secara lebih luas dan kemprehensif.

\section{PENUTUP}

Sebagai penutup uraian ini, dapat dikemukakan kesimpulan sebagai berikut (1) jihad adalah usaha yang sungguh-sungguh dan memerlukan banyak pengorbanan; (2) dalam Alquran hanya dua ayat yang menganjurkan untuk melakukan jihad dengan fisik. tetapi kebanyakan Alquran dan hadis nabi menganjurkan agar selalu berjihad dengan Alquran; (3) makna jihad selalu mengalami perubahan, sehingga jihad yang dilakukan oleh nabi saw. pada awalawal perkembangan Islam perlu dikaji kembali; (4) implementasi perintah jihad pada masa kini yang banyak meresahkan, merusak dan menteror, perlu ditinjau kembali; (5) sebaiknya jihad pada masa kini mengarah kepada pengkajian Alquran dan hadis nabi saw.; (6) diharapkan kepada generasi Islam masa kini agar memahami jihad secara lebih bijak, bukan sebagai kekerasan, pengrusakan, dan teror; dan (7) umat Islam hendaknya banyak mengkaji Alquran dan hadis nabi, seperti yang dilakukan nabi pada perkembangan Islam karena dewasa ini masih banyak umat Islam yang tidak mengerti esensi Alquran sebagai petunjuk.

\section{DAFTAR PUSTAKA}

Azzâm, 'Abd Allâh. 1992. Fi al-Jihâd: Adab wa Ahkâm. Beirut: Dâr ibn Hazm.

al-Ansârî, Jamâl al-Dîn Muh $\square$ ammad ibn Mukarram. t.th., Lisân al- 'Arab li ibn Manzûr t.tp.

al-Ashfahânî, al-Raghîb. t.th. Mu'jam Mufradât al-Fâz al-Qu'rân. Beirut: Dâr al-Fikr.

al-Baqâ', Abû 'Abd Allâh ibn al-H $\square$ usayn al-Khubânî. 1987. Al-Tibyân fî I'râb al-Qur'ân. Juz II. Beirut: Dâr al-Jill. 
al-Bajûri, Ibrâhîm. t.th. Bajûrî. Juz I. Mesir: Dâr al-Kutub al-'Arabiyat alKubrâ.

Ahmad Fâris ibn Zakariyâ. 1994. Mu'jam Maqâyyis al-Lughah. Beirut: Dâr al-Fikr.

Glasse, Cyrel. 1989. The Concise Encyclopedia of Islam. London: Stacey International.

Hâwî, Sa'ad. 1979. Jund Allâh Saqâfatan wa Akhlâqan. Beirut: Dâr alKutub al-'Ilmiyyah.

Husayn, Abû Muslim ibn Hajjaj al-Qushayrî, al-Naysabûrî. 1955 Sahîh Muslim. Juz I. Kairo: Dâr al-Bâb al-Halabî wa al-Shirkah.

Ibn Kathîr, Abû al-Fudâ' Ismâ'îl. 1990. Tafsîr al-Qur'ân al- 'Azîm. Beirut: Dâr al-Fikr.

R. von Der, Fred Masden \& Esposito John L. (Eds.). 1983. American Perception of Islam: Voices of Resurgent Islam. New York: Oxford University Pres.

Rashîd Ridâ, Muhammad. t.th. Tafsîr al-Manâr. Beirut: Dâr al-Fikr.

Saltût, Muhammad. 1969. Min Taujihât al-Islâm. Kairo: t. tp.

al-Shalih, Subhi. 1995. Membahas Ilmu-Ilmu Hadis. Jakarta: Pustaka Firdaus.

al-Shawkânî, Muhammad ibn Muhammad ibn 'Âlî. t.th. Fath al-Qadîr: AlJâmi' bayna Fann al-Riwâyah wa al-Dirâyah min al-Tafsîr. Juz III. Beirut: Dâr al-Ma'ârif. 